\title{
Nitrogen Mineralization from Sludge in an Alkaline, Saline Coal Gasification Ash Environment
}

\author{
Ikenna Mbakwe, ${ }^{*}$ Pieter C. De Jager, ${ }^{*}$ John G. Annandale, and Taurai Matema
}

Rehabilitating coal gasification ash dumps by amendment with waste-activated sludge has been shown to improve the physical and chemical properties of ash and to facilitate the establishment of vegetation. However, mineralization of organic $\mathrm{N}$ from sludge in such an alkaline and saline medium and the effect that ash weathering has on the process are poorly understood and need to be ascertained to make decisions regarding the suitability of this rehabilitation option. This study investigated the rate and pattern of $\mathrm{N}$ mineralization from sludge in a coal gasification ash medium to determine the prevalent inorganic $\mathrm{N}$ form in the system and assess the effect of ash weathering on $\mathrm{N}$ mineralization. An incubation experiment was performed in which fresh ash, weathered ash, and soil were amended with the equivalent of $90 \mathrm{Mg} \mathrm{ha}^{-1}$ sludge, and $\mathrm{N}$ mineralization was evaluated over $63 \mathrm{~d}$. More $\mathrm{N}(24 \%)$ was mineralized in fresh ash than in weathered ash and soil, both of which mineralized $15 \%$ of the initial organic $\mathrm{N}$ in sludge. More nitrification occurred in soil, and most of the $\mathrm{N}$ mineralized in ash was in the form of ammonium, indicating an inhibition of nitrifying organisms in the ash medium and suggesting that, at least initially, plants used for rehabilitation of coal gasification ash dumps will take up $\mathrm{N}$ mostly as ammonium.
Copyright $\odot$ American Society of Agronomy, Crop Science Society of America, and Soil Science Society of America. 5585 Guilford Rd., Madison, WI 53711 USA. All rights reserved. No part of this periodical may be reproduced or transmitted in any form or by any means, electronic or mechanical, including photocopying, recording, or any information storage and retrieval system, without permission in writing from the publisher.

J. Environ. Qual. 42:835-843 (2013)

doi:10.2134/jeq2012.0410

Received 21 Oct. 2012.

*Corresponding authors (mbakweikenna@gmail.com; Chris.DeJager@up.ac.za).
$\mathrm{G}$ ASIFICATION OF COAL to produce fuel may reduce the dependence on crude oil reserves, but the process leaves behind millions of tons of coal gasification ash (CGA). Gasification is the reaction of solid fuels with air, oxygen, steam, carbon dioxide, or a mixture of these gases at temperatures greater than $700^{\circ} \mathrm{C}$ to yield a gaseous product used as a source of energy or as a raw material for the synthesis of chemicals and fuels (Collot, 2006). There are about 160 modern gasification plants in operation worldwide that produce syngas, oxy-chemicals, methanol, hydrogen, and electricity (Minchener, 2005). South African Coal and Oil (Suid Afrikaanse Steenkool en Olie, Sasol) operates one of such plants, and, in its Lurgi coal gasification process, produces synthesis gas (a mixture of carbon monoxide and hydrogen) from low-grade, medium-rank C (bituminous) coal and extraneous rock fragments, usually carbonaceous shale, siltstone, sandstone, and mudstone (Matjie et al., 2008). The process, which takes place in gasifiers at elevated temperatures greater than $1350^{\circ} \mathrm{C}$ and pressures of more than 20 bar, generates the waste coal gasification ash. Matjie et al. (2005) estimates that at its Secunda plant, approximately 28 million tons of coal is consumed by the gasification process annually, and 7 million tons of CGA is produced. Gasification ash is a combination of red and white to grey fused clinkers with heterogeneous texture varying from fine material to large, irregularly shaped aggregates of sizes ranging from 4 to $75 \mathrm{~mm}$ and is composed predominantly of major oxides (quartz, mullite, and anorthite) and minor oxides (diopside, hematite, cristobalite) and anhydrite (Matjie et al., 2005).

The fact that ash reuse for purposes such as brick making has not kept up with the rate at which the waste is generated makes stockpiling of ash inevitable. The pollution risks associated with coal ash wastes have been well documented (e.g., Jala and Goyal, 2006). Acid rain characteristic of many industrial areas falling on these dumps could strip ash particles of salts and toxic elements and facilitate their transport. Moreover, dust carried by wind from these ash dumps could constitute major health hazards and degrade surface water bodies. It has thus become imperative to rehabilitate these ash dump sites.

The use of topsoil to cap ash dumps has been suggested (Van Rensburg et al., 1998); however, the consequent erosion of

\footnotetext{
I. Mbakwe, P.C. De Jager, and J.G. Annandale, Dep. of Plant Production and Soil Science, Univ. of Pretoria, Pretoria, 0002, Republic of South Africa; T. Matema, Agricultural Research Council-Institute for Soil Climate and Water, Private Bag X79, 0001, Pretoria, South Africa. Assigned to Associate Editor Stephen Del Grosso.
} 
arable topsoil and the costs of transporting soil to ash sites are major drawbacks with this rehabilitation option. One of the more recently proposed management options is the amendment of coal ash with sludge to aid rehabilitation of ash dump sites and as a viable sludge disposal system (Annandale et al., 2004). The use of sludge in rehabilitation efforts has been based on the premise that sludge would add necessary nutrients, improve physical attributes such as water holding capacity, and bind metals, thereby reducing their bioavailability and toxicity and allowing vegetation to be established (Scholl and Pase, 1984; Basta et al., 2001). The established vegetation reduces the spread of pollution by wind or water erosion and reduces water ingress and accompanying salt and metal leaching (Tandy et al., 2009).

Various studies, such as Van Rensburg et al. (1998) and Haynes (2009), have noted that amendment of coal ash with organic materials such as sludge improved the physical and chemical properties of the medium, making it more able to sustain vegetation. More importantly, sludge could supply a range of essential plant nutrients, mainly nitrogen $(\mathrm{N})$ and phosphorus.

Most of the $\mathrm{N}$ in sludge, however, is bound in organic forms, which have to be mineralized by microorganisms into plantusable $\mathrm{N}$ species. Nitrogen release from sludge has been shown to be affected by the properties of the medium in which it is applied (Hernández et al., 2002). The usefulness of amending CGA with sludge can only be realized if sufficient $\mathrm{N}$ is able to be mineralized from sludge in this highly alkaline and saline ash medium.

The effect of salinity and alkalinity on $\mathrm{N}$ mineralization from organic materials has been previously reported. Pathak and Rao (1998) observed a decrease in net $\mathrm{N}$ mineralization with increasing $\mathrm{pH}$ or salinity. They also found that ammonification continued to take place at electrical conductivity (EC) levels that inhibited nitrification, confirming earlier studies that ammonifiers are more tolerant of salinity than nitrifiers (McClung and Frankenberger, 1985). Although most of the studies on N mineralization from organic materials have been done on soil, studies dealing with $\mathrm{N}$ mineralization in nonsoil media such as coal ash have been rare. Fang et al. (1999) reported $\mathrm{N}$ dynamics after cocomposting sewage sludge and coal fly ash. Apart from the high temperature conditions of the cocomposting process, it is not clear whether the same observations can be detected in ash from coal gasification processes under temperature conditions expected in actual ash dumps. Ginster and Matjie (2005) noted that coal gasification ash differs from coal fly ash from power stations in chemical and mineralogical characteristics.

It is unclear to what extent mineralization of organic $\mathrm{N}$ is attainable in a CGA medium where a high $\mathrm{pH}$ is compounded by a high EC. It is imperative to understand the rate at which inorganic $\mathrm{N}$ is released from sludge applied on gasification ash dumps to ensure that sufficient $\mathrm{N}$ is available for vegetation while excessive generation of nitrates is avoided. It is also critical to determine which inorganic $\mathrm{N}$ forms are prevalent in such a system if mineralization of organic $\mathrm{N}$ does take place. Microbial species involved in nitrification are especially sensitive to high $\mathrm{pH}$, suggesting that ammonium might be abundant in these alkaline media. Moreover, because nitrite oxidizers are inhibited by free ammonia to a greater extent than ammonium oxidizers (Smith et al., 1997), excess ammonium could lead to an accumulation of nitrite.

Furthermore, the effect of ash weathering on $\mathrm{N}$ mineralization would be an important consideration to make in deciding when to apply sludge to CGA dumps. Weathered ash may have more negatively charged surfaces than fresh ash, with implications for ammonium attenuation. On the other hand, the ameliorating effect of weathering on salt content and electrical conductivity may create a more hospitable medium for nitrifying bacteria.

The objectives of this study were (i) to determine the rate and pattern of $\mathrm{N}$ mineralization from sludge in a coal gasification ash medium, (ii) to determine the prevalent inorganic $\mathrm{N}$ form in the system, and (iii) to assess the effect of ash weathering on $\mathrm{N}$ mineralization. The following hypotheses were tested: (i) There would be less $\mathrm{N}$ mineralization in sludge-amended ash than in sludge-amended soil due to the high $\mathrm{pH}$ and high salinity of the ash medium; (ii) ammonium will dominate in sludge-amended ash because nitrifying bacteria are sensitive to high $\mathrm{pH}$; and (iii) more $\mathrm{N}$ mineralization will occur in sludgeamended weathered ash than in sludge-amended fresh ash due to the ameliorating effect that weathering has on salinity.

\section{Materials and Methods}

Estimates of organic $\mathrm{N}$ mineralization rates from sludge usually rely on incubation studies (field or laboratory), crop $\mathrm{N}$ uptake studies (field or greenhouse), average mineralization rates of biosolid treatment (processing/stabilization) methods, and regression equations based on biosolid organic $\mathrm{N}$ content (Henry et al., 1999). In this study, mineralization rates and patterns were evaluated using incubation procedures.

\section{Preparation of Materials}

Coal gasification ash was collected from Sasol Synfuels in Secunda, South Africa. Gasification ash, delineated as "fresh ash," was collected from a freshly dumped ash heap. Gasification ash, delineated as "weathered ash," is fresh ash that had undergone 10 laboratory leaching and drying cycles over a period of $1 \mathrm{yr}$. The total amount of water used during the column leaching process was equivalent to $1270 \mathrm{~mm}$ of rainfall, corresponding to the amount of rainfall received in Secunda in about $2 \mathrm{yr}$ (Jovanovic et al., 2004). Details of the column leaching setup can be found in De Jager et al. (2011). The sludge used for this study was obtained from Sasol's activated sludge treatment plant. The sludge originated from the treatment of domestic and industrial wastewater and has a C:N ratio of $7: 1$. Topsoil $(0-15 \mathrm{~cm})$ of a loamy sand was collected from an experimental farm of the University of Pretoria near Cullinan, Gauteng Province, South Africa, where sludge has not previously been applied. Soil was included in this experiment to compare sludge $\mathrm{N}$ mineralization in ash with $\mathrm{N}$ mineralization in a more common sludge application medium. Nitrogen speciation and some chemical characteristics of coal gasification ash, soil, and sludge determined in a 1:5 sample:water mixture are shown in Table 1.

Soil and gasification ash were air dried and passed through a 2-mm sieve. Sludge was air dried and milled. Water retention characteristics of CGA and soil were generated based on the relationship between water potential and water content using 
a Dew Point Potentiometer (WP4, Decagon Devices). Due to the high water absorption capability of gasification ash and to use a uniform water potential for ash and soil, water contents corresponding to $-70 \mathrm{kPa}$ were chosen for soil and gasification ash.

\section{Incubation and Chemical Analysis}

Ten grams of soil or fresh or weathered ash were weighed into 100-mL containers and amended with 5\% dry sludge. The choice of $5 \%$ sludge was made on the basis of heavy metal release studies, which showed that amending CGA with more than 5\% dry Sasol sludge may increase the solubility of certain metals to levels of environmental concern (De Jager et al., 2011). Assuming a bulk density of $1200 \mathrm{~kg} \mathrm{~m}^{-3}$ and a depth of $15 \mathrm{~cm}$, the rate of sludge amendment was equivalent to $90 \mathrm{Mg}$ of dry sludge per hectare. The containers used for incubation had airtight lids to maintain constant water contents. A headspace was left above the mixtures to aid aeration.

Treatments were wet to the predetermined water content at $-70 \mathrm{kPa}$. Nitrogen mineralization from unamended soil and ash served as controls; this value was subtracted from mineralization observed from amended samples to determine the actual mineralization from sludge. Although this approach downplays the phenomenon of a "priming effect," it is widely accepted for estimating mineralization rates from organic materials (Agehara and Warncke, 2005). Priming is a phenomenon that is observed when fresh substrates used for soil amendment accelerate $\mathrm{N}$ mineralization in such a way that the amount of $\mathrm{N}$ mineralized is greater than the amount of $\mathrm{N}$ mineralized from the substrates added and the amount of $\mathrm{N}$ mineralized from unamended soil.

Triplicate treatments were made for sampling days $0,7,21$, $28,35,56$, and 63 . For each sampling day, unamended soil, fresh ash, and weathered ash served as controls. Treatments were maintained at $25 \pm 3^{\circ} \mathrm{C}$ and aerated weekly for about 5 min to keep the system oxidized. Water loss was checked by weighing to keep the treatments at the required water content.
On the sampling days, $50 \mathrm{~cm}^{3}$ of distilled water was added to the samples, which were then shaken in a reciprocating shaker at 200 oscillations per minute for $60 \mathrm{~min}$. $\mathrm{pH}$ was measured with a glass electrode, and EC measurements were taken thereafter. Samples were filtered through Whatman no. 1 filter paper and stored below $4^{\circ} \mathrm{C}$ until analysis. Inorganic $\mathrm{N}$ was determined in a segmented Technicon (SEAL Analytical) flow autoanalyzer system (Bremner, 1965). Total $\mathrm{N}$ was determined after acid digestion (Bremner, 1996). Organic $\mathrm{N}$ was taken as the difference between total $\mathrm{N}$ and inorganic $\mathrm{N}$.

The cumulative $\mathrm{N}$ mineralized $\left(\mathrm{N}_{\text {min }}\right)$ from unamended soil or ash at time $t,\left(\mathrm{~N}_{\text {min }}\right)$ control, was calculated by:

$\left(\mathrm{N}_{\min }\right)$ control $=$ Inorganic $\mathrm{N}(\text { control })_{t}-$ Inorganic $\mathrm{N}(\text { control })_{t=0}$

Nitrogen mineralized from sludge was given as the sum of the inorganic forms of the $\mathrm{N}$ in sludge-amended soil/ash adjusted for mineralization of soil/ash $\mathrm{N}$ and the initial inorganic $\mathrm{N}$ added with the sludge. The cumulative amount of $\mathrm{N}$ mineralized from sludge at time $t$ was therefore calculated by:

$\left(\mathrm{N}_{\text {min }}\right)_{\text {sludge }}=(\text { Inorganic } \mathrm{N} \text { of sludge-amended treatment })_{t}-$

(Inorganic $\mathrm{N}$ of control) $t$ - (Inorganic $\mathrm{N}$ added with sludge)

Percent organic $\mathrm{N}$ mineralized was estimated as:

$\%$ organic $\mathrm{N}_{\min }=(\mathrm{N}$ mineralized/organic $\mathrm{N}$ added $) \times 100$

\section{Statistical Analysis}

Data were analyzed by ANOVA in a completely randomized design using the General Linear Model procedures of Windows SAS version 9.0 (SAS Institute, 2002). When treatment effects were found to be significant, separation of means was performed using the Tukey test.

The rate of $\mathrm{N}$ mineralization from sludge was estimated using the model proposed by Smith et al. (1980):

$\mathrm{N}_{\min }=\mathrm{N}_{0}[1-\exp (-k t)]$

Table 1. Some chemical characteristics of experimental materials $\dagger$

\begin{tabular}{|c|c|c|c|c|}
\hline & Fresh ash & Weathered ash & Soil & Sludge \\
\hline $\mathrm{pH}\left(\mathrm{H}_{2} \mathrm{O}\right)$ & $8.71(0.08)$ & $9.46(0.04)$ & $5.58(0.035)$ & $5.8(0.03)$ \\
\hline $\mathrm{EC}, \neq \mathrm{dS} \mathrm{m}^{-1}$ & $2.02(0.02)$ & $0.53(0.005)$ & $0.096(0.0016)$ & $0.65(0.07)$ \\
\hline Total N, \% & $0.0095(0.0028)$ & $0.00925(0.001)$ & $0.024(0.00014)$ & $7.91(0.006)$ \\
\hline $\mathrm{NH}_{4}-\mathrm{N}, \mathrm{mg} \mathrm{kg}^{-1}$ & $1.25(0.036)$ & $1.21(0.012)$ & $20.9(0.88)$ & 7104 (356.2) \\
\hline $\mathrm{NO}_{3}-\mathrm{N}, \mathrm{mg} \mathrm{kg}^{-1}$ & $7.2(0.65)$ & $2.33(0.11)$ & $22.1(1.32)$ & $167(6.7)$ \\
\hline $\mathrm{NO}_{2}-\mathrm{N}, \mathrm{mg} \mathrm{kg}^{-1}$ & $1.34(0.1)$ & $0.54(0.019)$ & $0.75(0.39)$ & $8.71(0.79)$ \\
\hline Organic N, mg kg ${ }^{-1}$ & 85 (29.05) & $88(10.49)$ & $196(5.01)$ & $71820(336.9)$ \\
\hline $\mathrm{Ca}, \mathrm{mg} \mathrm{kg}^{-1}$ & $1517(53)$ & 462 (7.9) & $17.8(3.1)$ & $394(2.1)$ \\
\hline $\mathrm{Mg}, \mathrm{mg} \mathrm{kg}^{-1}$ & $94.8(2.5)$ & $7.4(0.4)$ & $8.7(1.2)$ & $299(2.8)$ \\
\hline $\mathrm{K}, \mathrm{mg} \mathrm{kg}^{-1}$ & $158(4.7)$ & $18.6(0.53)$ & $12.2(1.7)$ & 851 (18.9) \\
\hline $\mathrm{Na}, \mathrm{mg} \mathrm{kg}^{-1}$ & $480(14.7)$ & $35(2.0)$ & $5.8(1.9)$ & $371(8.7)$ \\
\hline $\mathrm{Fe}, \mathrm{mg} \mathrm{kg}^{-1}$ & $0.035(0.0095)$ & $0.026(0.0075)$ & $42.19(1.33)$ & $8.98(0.14)$ \\
\hline $\mathrm{Al}, \mathrm{mg} \mathrm{kg}^{-1}$ & $0.653(0.03)$ & $2.68(0.05)$ & $126.97(29.5)$ & $10.13(0.08)$ \\
\hline $\mathrm{Cu}, \mathrm{mg} \mathrm{kg}^{-1}$ & $0.016(0.003)$ & $0.012(0.0025)$ & $0.128(0.026)$ & $0.235(0.03)$ \\
\hline $\mathrm{Mn}, \mathrm{mg} \mathrm{kg}^{-1}$ & $0.0189(0.0027)$ & $0.0039(0.001)$ & $2.705(0.54)$ & $5.38(0.025)$ \\
\hline $\mathrm{Zn}, \mathrm{mg} \mathrm{kg}^{-1}$ & $0.162(0.014)$ & $0.0068(0.00076)$ & $0.83(0.03)$ & $2.69(0.29)$ \\
\hline
\end{tabular}

† Values represent the mean SD in parentheses.

‡ Electrical conductivity. 
where $\mathrm{N}_{\min }$ is the amount of $\mathrm{N}$ mineralized from sludge at a specific time $(t), \mathrm{N}_{0}$ is the potentially mineralizable organic $\mathrm{N}$, $k$ is the first-order rate constant, and $t$ is the time of incubation.

\section{Results and Discussion}

\section{pH and Electrical Conductivity}

Weathered unamended ash had a higher $\mathrm{pH}$ than fresh ash (Fig. 1). The exposure of ash to air $\left(\mathrm{CO}_{2}\right)$ and water during the process of leaching and weathering is capable of liberating the more alkaline compounds of ash. During that process, calcium oxide is converted to the more alkaline calcium hydroxide and ultimately to $\mathrm{CaCO}_{3}$. In unamended ash samples, $\mathrm{pH}$ remained fairly constant over the 63-d period, whereas it showed a decline in unamended soil. The $\mathrm{pH}$ of soil declined from 5.58 at the start of the incubation to 4.59 on Day 63. This decline is attributed to the acidifying effects of the process of nitrification (Brady and Weil, 1999).

The addition of sludge significantly $(\alpha=0.05)$ reduced the $\mathrm{pH}$ of fresh ash from 8.7 to 8.0 and of weathered ash from 9.5 to 8.6 at the start of incubation. $\mathrm{pH}$ was further reduced at Day 7 to 7.95 for fresh ash and 8.09 for weathered ash and remained near these values throughout the incubation period. This reduction of $\mathrm{pH}$ is linked to the net effect of the mineralization process and to carbonation, a situation where carbon dioxide released during the breakdown of sludge forms carbonic acid. A reduction of $\mathrm{pH}$ is one of the benefits accruable from amending ash with sludge because nutrient deficiencies are common in high alkaline conditions.
The $\mathrm{pH}$ of sludge-amended soil increased at the start of the incubation and with time up to Day 21. At Day 0, sludgeamended soil had a $\mathrm{pH}$ of 6.32, and at Day 21, $\mathrm{pH}$ was 8.75, after which $\mathrm{pH}$ remained fairly constant and similar to sludgeamended ash. This increase in $\mathrm{pH}$ can be attributed to the hydrolysis of urea in sludge to unstable carbamic acid, which decomposes rapidly to form ammonia and carbon dioxide. The reaction of ammonia with water results to the formation of ammonium and the hydroxide ion, which increases the local microsite pH (Coyne, 1999).

Fresh ash had significantly $(\alpha=0.05)$ higher EC than weathered ash and soil. At the Sasol Synfuels plant, brines are used for ash transport in a wet ash/slurry transport system, and the high-salt effluents from the tubular reverse osmosis process obtained during the treatment of Clear Ash Effluent are deposited on the ash heap to limit salt mobility; for example, $\mathrm{SO}_{4}$ was found to be retained in a stable phase in the ash (Van den Berg, 2004). During ash weathering, exposure of ash to leaching removes soluble salts from ash (Haynes, 2009). For unamended treatments, EC was $2.02 \mathrm{dS} \mathrm{m} \mathrm{m}^{-1}$ for fresh ash, $0.53 \mathrm{dS} \mathrm{m} \mathrm{m}^{-1}$ for

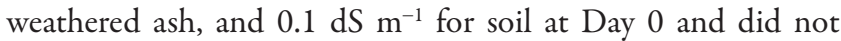
change drastically throughout the incubation period.

The EC of the three materials increased significantly $(\alpha=$ 0.05 ) on addition of sludge. At Day 0 , the EC values of sludgeamended samples were $2.27 \mathrm{dS} \mathrm{m} \mathrm{m}^{-1}$ for fresh ash, $0.83 \mathrm{dS} \mathrm{m}^{-1}$ for weathered ash, and $0.39 \mathrm{dS} \mathrm{m} \mathrm{m}^{-1}$ for soil. An increase of EC after sludge amendment has been widely reported (e.g., Tsadilas et al., 1995; Tesfamariam et al., 2009) and is attributed to the soluble salts in sludge and to ligand promoted dissolution, which is capable of liberating salts from sludge-amended

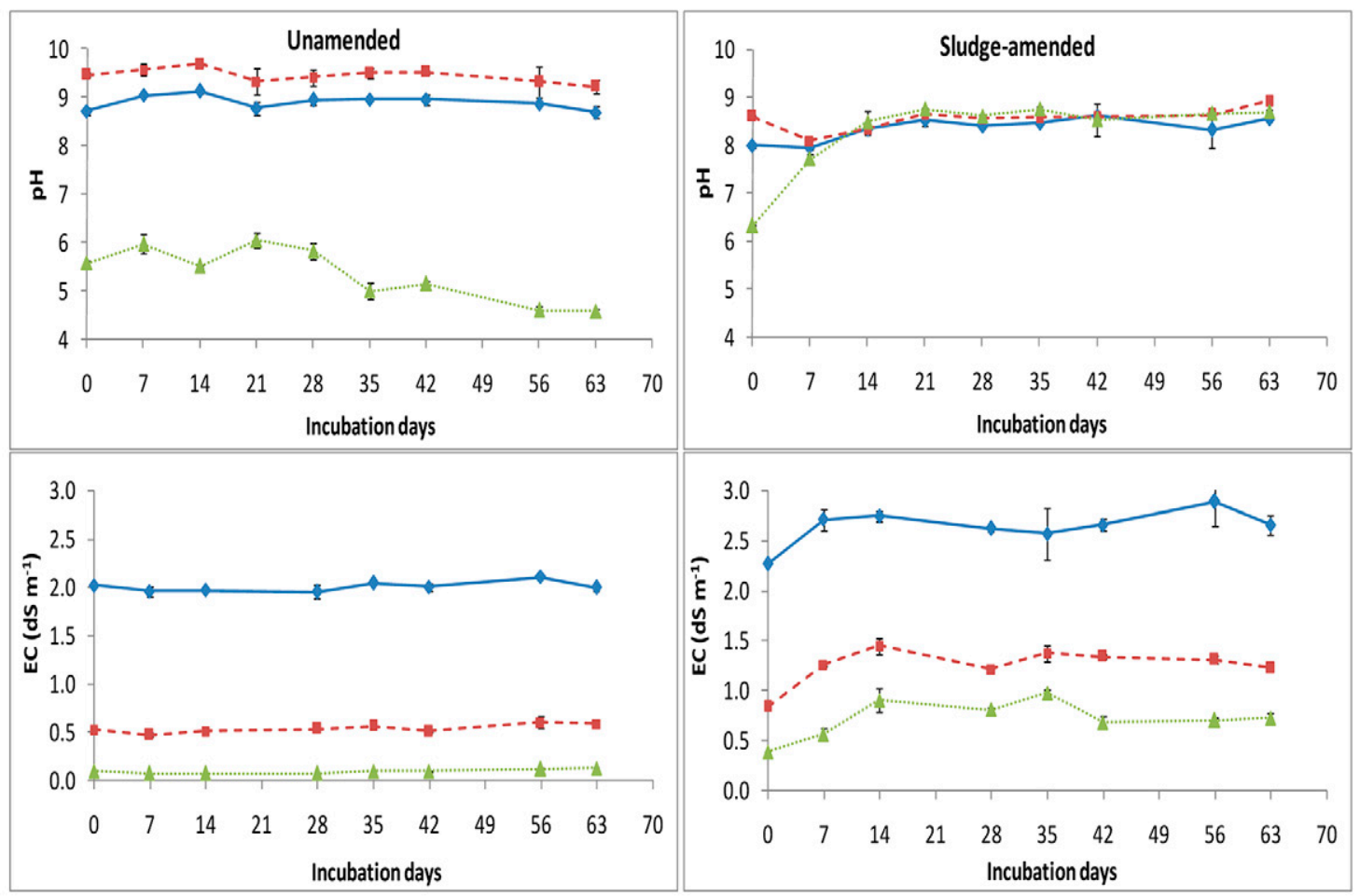

Key: $\longrightarrow$ Fresh ash $\quad$ - Weathered ash …... Soil

Fig. 1. pH and electrical conductivity (EC) of unamended and sludge-amended fresh ash, weathered ash, and soil during a 63-d incubation. Error bars show SD of replicates. 
media. Amending ash with sludge for revegetation purposes will therefore have to take into account the high EC resulting from sludge addition, and salinity-tolerant plant species may have to be considered. Annandale et al. (2004) and Van Rensburg et al. (1998) found that Cynodon dactylon adapted well to conditions in sludge-amended coal ash. Khan et al. (1999) and Hameed and Ashraf (2008) have also cited the salt tolerance of Cynodon dactylon.

\section{Ammonium, Nitrite, and Nitrate}

Ammonium in unamended samples increased slightly from 1.25 to $12 \mathrm{mg} \mathrm{kg}^{-1}$ for fresh ash, from 1.21 to $9.4 \mathrm{mg} \mathrm{kg}^{-1}$ for weathered ash, and from 20.9 to $29.3 \mathrm{mg} \mathrm{kg}^{-1}$ for soil during the incubation period (Fig. 2). Upon addition of sludge, ammonium increased to approximately $200 \mathrm{mg} \mathrm{kg}^{-1}$ for all treatments at the start of the experiment. For sludge-amended samples, ammonium steadily increased, reaching a maximum on Day 35 of $1240 \mathrm{mg} \mathrm{kg}^{-1}$ for fresh ash, $886 \mathrm{mg} \mathrm{kg}^{-1}$ for weathered ash, and
$936 \mathrm{mg} \mathrm{kg}^{-1}$ for soil. The decrease of ammonium after Day 35 is attributed to volatilization due to a high $\mathrm{pH}$ and to conversion of ammonium to nitrite and nitrates.

Ammonium levels were higher for fresh ash than for weathered ash and soil over the incubation period. Because ash weathering leads to the formation of clay minerals, it is suggested that the lower ammonium levels in weathered ash and soil are due to clay protection of organic matter from mineralization or due to clay adsorption of ammonium. Zevenbergen et al. (1999) noted that, over time, weathering causes a transformation of the ash components converting alumino-silicate glass into noncrystalline clay minerals. Binding of proteins such as urease to clays may hide the specific peptide bonds that extracellular proteases require to decompose the proteins. Proteins may also be protected in micropores that are too small for microorganisms to enter (Coyne, 1999).

In soil, little attention has been paid to nitrite because of analytical difficulties (Isobe et al., 2012) and because, under
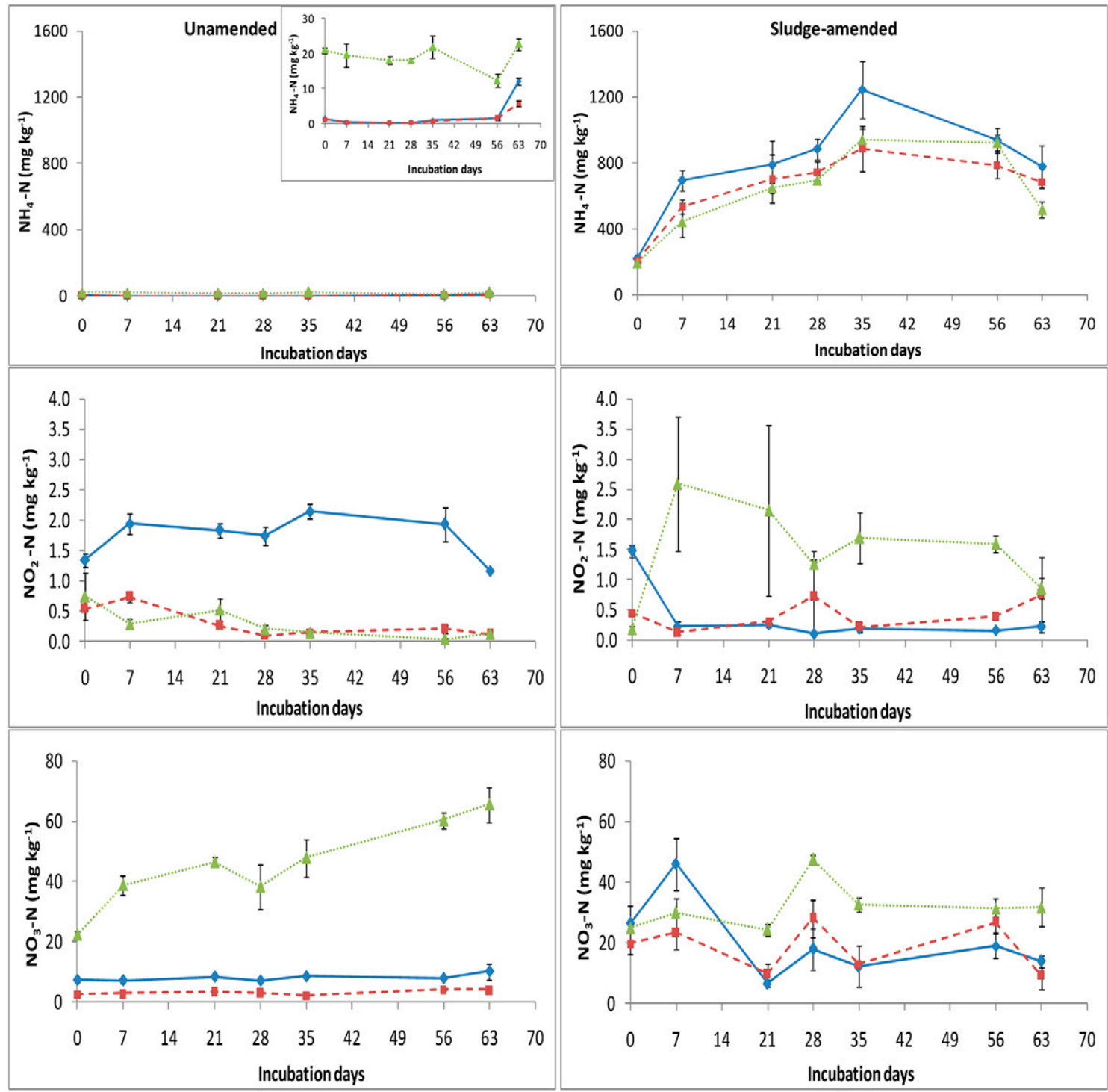

Key:

$\longrightarrow$ Freshash $\quad$ E- Weathered ash ….... Soil

Fig. 2. Ammonium, nitrite, and nitrate concentrations of unamended and sludge-amended fresh ash, weathered ash, and soil during a 63-d incubation. Error bars show SD of replicates. 
favorable conditions, transformation of nitrites to nitrates is rapid and accumulation of nitrite is negligible (Nishio and Fujimoto, 1990). However, in an alkaline medium with high inputs of ammonium, nitrite dynamics may be different, and this warrants investigation.

Unamended fresh ash had a higher content of nitrites than unamended weathered ash or soil. During gasification of coal, $\mathrm{NH}_{3}$ is introduced into the electrostatic precipitator to enhance the removal of fly ash. Under conditions of high alkalinity and salinity, oxidation of the introduced $\mathrm{NH}_{3}$ may only yield nitrite. Leaching of ash during ash weathering would have resulted in removal of nitrite in the leachates.

For unamended soil, nitrite decreased progressively during the incubation period as a result of oxidation to nitrates. It decreased from $0.75 \mathrm{mg} \mathrm{kg}^{-1}$ on Day 0 to a minimum of $0.04 \mathrm{mg} \mathrm{kg}^{-1}$ on Day 56. Nitrite levels increased rapidly when soil was amended with sludge and then decreased as incubation progressed. This initial increase can be attributed to the oxidation of ammonium to nitrites. Under favorable conditions, this process should proceed rapidly, and nitrite should not accumulate. However, because of the build-up of ammonium, nitrite may accumulate. Smith et al. (1997) suggested that nitrite oxidizers can be inhibited by free ammonia to a greater extent than ammonium oxidizers. The build-up of nitrite $\left(\mathrm{NO}_{2}{ }^{-}\right)$and hydroxylamine $\left(\mathrm{NH}_{2} \mathrm{OH}\right)$, which are toxic to nitrifying bacteria, further inhibits nitrification.

Amending fresh ash with sludge reduced the concentration of nitrite possibly because of nitrite fixation and volatilization in the presence of organic matter. Bremner and Führ (1966) were among the first to point out the fixation of nitrite by soil organic matter. Moreover, volatilization of nitrite has been found to increase with increased soil organic matter (Nelson and Bremner, 1969). Nelson and Bremner (1970) reported that after soils were treated with nitrite under aerobic conditions, nitrite decomposition led to the formation of substantial amounts of $\mathrm{NO}_{2}$ and $\mathrm{N}_{2}$ and small amounts of $\mathrm{N}_{2} \mathrm{O}$, with the largest amount of $\mathrm{N}_{2}$ formed in the soil with the highest organic matter content. In soil where conditions are more conducive for nitrification, the intensity of the nitrite-generating process may have exceeded processes that deplete nitrite.

Nitrite was the $\mathrm{N}$ form with the lowest concentration among the three inorganic $\mathrm{N}$ forms investigated. The reduction of nitrite on addition of sludge to fresh ash is a benefit with respect to environmental mitigation and will aid in plant establishment. Plants affected by nitrite toxicity are small, chlorotic, and prone to wilting. Nitrite toxicity is $\mathrm{pH}$ dependent. At $\mathrm{pH} 7$ plants can tolerate up to $200 \mathrm{mg}$ $\mathrm{NO}_{2}-\mathrm{N} \mathrm{kg}^{-1}$, whereas at $\mathrm{pH} 4$ a nitrite concentration of only 2 $\mathrm{mg} \mathrm{NO}-\mathrm{N} \mathrm{kg}^{-1}$ is toxic. At $\mathrm{pH}$ of about 5.5 , as little as $15 \mathrm{mg}$ $\mathrm{NO}_{2}-\mathrm{N} \mathrm{kg}^{-1}$ is toxic to lettuce, whereas $5 \mathrm{mg} \mathrm{NO}-\mathrm{N} \mathrm{kg}^{-1}$ is toxic to tobacco (Cleemput and Samater, 1995).

Nitrate was increasingly generated in unamended soil from $22 \mathrm{mg} \mathrm{kg}^{-1}$ at the start of incubation to $65 \mathrm{mg} \mathrm{kg}^{-1}$ on Day 63 . A soil $\mathrm{NO}_{3}-\mathrm{N}$ concentration of between 21 and $25 \mathrm{mg} \mathrm{kg}^{-1}$ has been found to be sufficient for optimum yield of corn (Fox et al., 1989). Sludge-amended soil, however, resulted in relatively lower levels of $\mathrm{NO}_{3}-\mathrm{N}$. This can be attributed to the higher $\mathrm{pH}$ and EC of sludge-amended soil and to the inhibitory effects of excess ammonium on the activities of nitrifying organisms. Nishio and Fujimoto (1990) found that nitrification was inhibited at ammonium concentrations $>300 \mathrm{mg} \mathrm{kg}^{-1}$. High ammonium input to alkaline soils has been found to inhibit oxidation of nitrite to nitrate (Shen et al., 2003).

Nitrate formation occurred in sludge-amended ash, although less than in soil. The organisms involved in converting ammonium to nitrates may have been inhibited by the higher $\mathrm{pH}$ and $\mathrm{EC}$ of ash. Fang et al. (1999) cocomposted sewage sludge and coal fly ash and observed that ash inhibited nitrification.

Ammonium was the more dominant inorganic $\mathrm{N}$ species in sludge-amended ash. If plants are established on ash dumps, this has important implications on the ionic balance of the rhizosphere. Plants take up $\mathrm{N}$ from the soil solution mainly as $\mathrm{NO}_{3}{ }^{-}$and $\mathrm{NH}_{4}{ }_{4}$ ions. The relative amounts of these ions taken up by plant roots affect the $\mathrm{pH}$ of the soil solution in close proximity to plant roots. Nitrate anions exchange with $\mathrm{HCO}_{3}^{-}$ or $\mathrm{OH}^{-}$at the root surface, thereby causing an increase in the $\mathrm{pH}$ of the soil solution around plant roots. When ammonium cations are absorbed, they exchange with hydrogen ions, thereby lowering the $\mathrm{pH}$ of the solution around the rhizosphere (Brady and Weil, 1999). With time this may ameliorate the high $\mathrm{pH}$ of coal ash dumps.

\section{Total Inorganic Nitrogen and Nitrogen Mineralized from Sludge}

Some studies have calculated the rate of mineralization by the decrease in organic N. Others follow the approach of calculating the increase in inorganic N. Ideally, both approaches should give the same results. In this study, the increase in inorganic $\mathrm{N}$ is used to determine rate of mineralization. Nitrogen losses by volatilization of ammonia were not evaluated; thus, this approach may underestimate mineralized N. Nevertheless, regarding the environment and plant establishment, ammonium, nitrites, and nitrates are the more relevant species.

Mineralization proceeded rapidly up to the 35th day of incubation (Fig. 3). Hernández et al. (2002) also found that mineralization from sludge was rapid in the early stages of incubation. This increase in rate within the early periods of incubation is attributed to the mineralization of the easily mineralizable organic $\mathrm{N}$ pool. Sludge has been shown to contain different pools of organic $\mathrm{N}$ with differing rates of mineralization (Rowell et al., 2001; Gil et al., 2011). Unstabilized sludge characterized by a high content of volatile solids, such as that one used in this study, has been reported to contain more of the easily mineralizable organic $\mathrm{N}$ pool than those with a higher stability (Henry et al., 1999; Nobela, 2011). As this disappears, leaving the more recalcitrant pool, mineralization rate decreases. Moreover, at the beginning of the incubation, $\mathrm{N}$ mineralized exceeds the $\mathrm{N}$ needs of the microbial population, leading to a net increase in inorganic $\mathrm{N}$.

The decrease in inorganic $\mathrm{N}$ after Day 35 may be the result of gaseous losses of $\mathrm{N}$ due to ammonia volatilization (Martines et al., 2010). Denitrification is not a likely process due to the aerobic nature of the experiment. A rise in $\mathrm{pH}$ may lead to increased loss of $\mathrm{N}$ through volatilization. Dendooven et al. (2010) observed that amending ash with sludge may give rise to large losses of ammonium due to ammonia volatilization but that this may be reduced by incorporating sludge into the ash. 


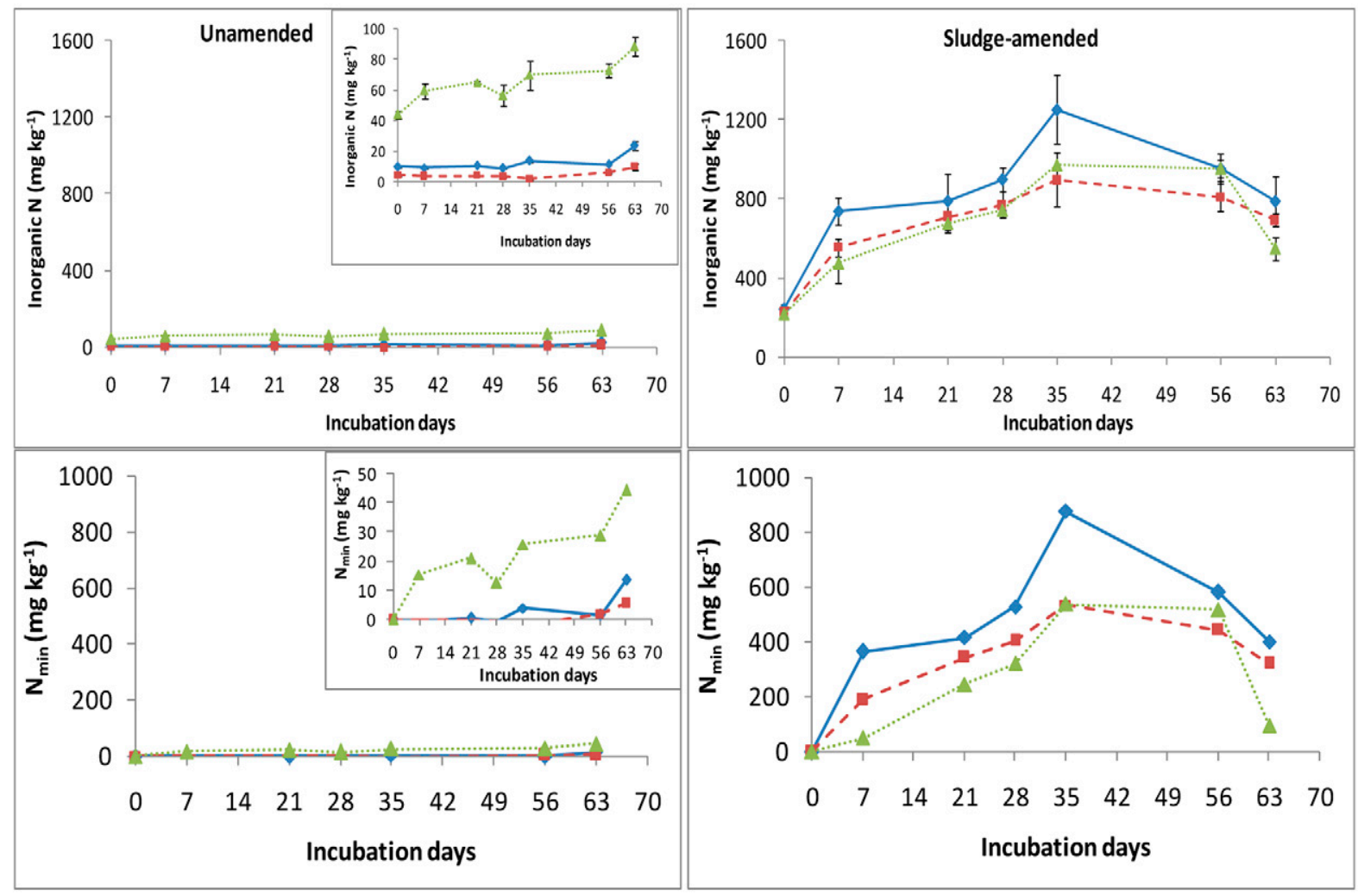

Key: $\longrightarrow$ Fresh ash - - Weathered ash … Woil

Fig. 3. Total inorganic $\mathrm{N}$ and $\mathrm{N}$ mineralized in unamended and sludge-amended fresh ash, weathered ash, and soil during a 63-d incubation. Error bars show SD of replicates.

Nitrogen mineralized from sludge-amended ash was more than sufficient and even exceeded the $\mathrm{N}$ requirements of many pasture crops (Mears, 1970). This has to be taken into consideration so that, although applying sludge to ash aids in sludge disposal, excess ammonium generated does not become an environmental problem. Lower rates of sludge application will be adequate to meet plant $\mathrm{N}$ needs.

Contrary to the hypothesis, more $\mathrm{N}$ was mineralized from fresh ash than from weathered ash and soil. The greater attenuation of organic matter in weathered ash and soil due to the presence of more clay minerals is a possible explanation. On Day 35, the difference in $\mathrm{N}$ mineralized was significant $(\alpha=0.05)$ between fresh ash and weathered ash. There was no significant difference $(\alpha=0.05)$ between $\mathrm{N}$ mineralized in weathered ash and $\mathrm{N}$ mineralized in soil. In fresh ash, $24 \%$ of organic $\mathrm{N}$ was mineralized, whereas $15 \%$ was mineralized in weathered ash and soil.

Nitrogen mineralization was low in soil. Having already a substantial amount of ammonium, the addition of sludge may have resulted in an impediment of the relevant microorganisms in soil by the build-up of ammonium. Moreover, the coarser texture of gasification ash may have aided mineralization. Hernández et al. (2002) found more mineralization of $\mathrm{N}$ in a sandy loam than in a clayey loam and attributed this to better aeration in the light-textured soil, which accelerated sludgeorganic $\mathrm{N}$ decomposition.

Mineralization of organic N from sludge over the first $35 \mathrm{~d}$ was well approximated using first-order kinetics, with resulting high $R^{2}$ values. Figure 4 shows the rate constants calculated using the model proposed by Smith et al. (1980) (Eq. [4]). When $\ln \left[1-\left(\mathrm{N}_{\min } / \mathrm{N}_{0}\right)\right]$ is plotted against incubation days, the slope of the graph gives the rate constant per day.

Rate constants were $0.0064 \mathrm{~d}^{-1}$ for fresh ash, $0.0042 \mathrm{~d}^{-1}$ for weathered ash, and $0.0044 \mathrm{~d}^{-1}$ for soil. These values are smaller than the value of $0.013 \mathrm{~d}^{-1}$ found by Nobela (2011) using the Sasol synfuels sludge on soil at a rate of $10 \mathrm{Mg} \mathrm{ha}^{-1}$ at similar moisture and temperature conditions. The inhospitality of the ash medium and the higher sludge rate and consequent ammonium toxicity are put forward as reasons for the lower mineralization rate in this study. In Nobela's study, sludge obtained from the Sasol Synfuels facility had the highest mineralization rate compared with the municipal sludges used in that experiment, attributable to Sasol sludge having the highest total $\mathrm{N}$ and volatile solid content.

In actual coal gasification ash heaps, particles larger than the 2-mm maximum size used in this experiment are common. However, in this laboratory study, for proper comparison with soil, a uniform maximum particle size had to be used. Rates of $\mathrm{N}$ mineralization in sludge-amended ash heaps might therefore differ slightly from those calculated in this study. Nevertheless, these results give an indication of the trends expected.

\section{Conclusions}

Organic $\mathrm{N}$ from sludge was mineralized in a coal gasification ash medium. More $\mathrm{N}$ was mineralized in fresh ash than in weathered ash and soil, and the dominant inorganic $\mathrm{N}$ form 

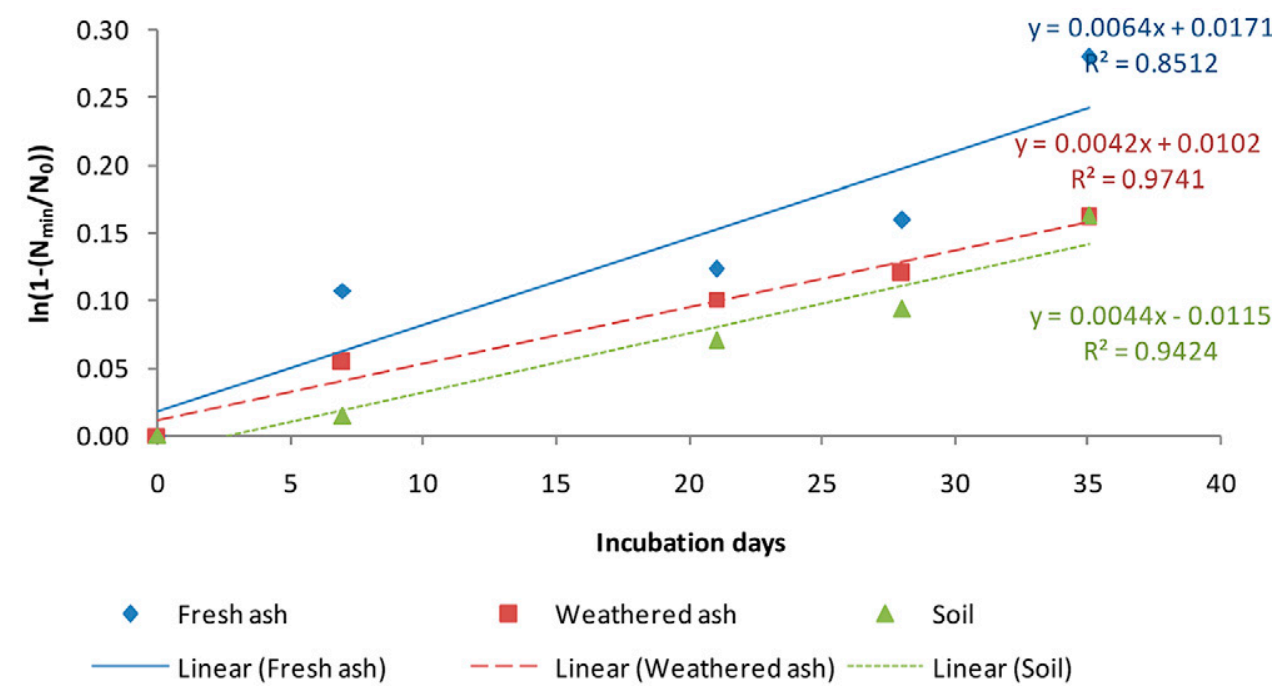

Fig. 4. Nitrogen mineralization rate constants for sludge-amended fresh ash, weathered ash, and soil in the first $35 \mathrm{~d}$ of incubation.

in sludge-amended ash was ammonium; therefore, only the hypothesis that ammonium will dominate in sludge-amended ash is accepted. The low nitrification observed in sludge-amended ash implies that, at least initially, plants grown on these amended dumps will take up $\mathrm{N}$ mostly as ammonium. Moreover, the potential for nitrate leaching is low. It is recommended that for rehabilitation purposes, management should aim to balance the $\mathrm{N}$ needs of vegetation with rates of $\mathrm{N}$ mineralization calculated under the prevailing conditions.

\section{Acknowledgements}

This study was supported by the Water Research Commission and Sasol. The authors thank Lot Mokoena of the ARC-ISCW and Charl Hertzog for technical guidance with analysis and anonymous reviewers for helpful suggestions.

\section{References}

Agehara, S.W., and D. Warncke. 2005. Soil moisture and temperature effects on nitrogen release from organic nitrogen sources. Soil Sci. Soc. Am. J. 69:1844-1855. doi:10.2136/sssaj2004.0361

Annandale, J.G., H.J.C. Smith, W.F. Truter, and M. Herbert. 2004. The rehabilitation of a coarse ash dump: Investigating opportunities to codispose SASOL waste materials with coarse ash, and negate the need for expensive soil covers. University of Pretoria and Fractal Forest Africa CC to SASOL, Pretoria, South Africa.

Basta, N., J. Schroder, R. Gradwohl, and K. Snethen. 2001. Chemical immobilization of lead, zinc, and cadmium in smelter-contaminated soils using biosolids and rock phosphate. J. Environ. Qual. 30:1222-1230. doi: $10.2134 /$ jeq2001.3041222x

Brady, N.C., and R.R. Weil. 1999. The nature and properties of soils. 12th ed. Prentice Hall, New Jersey.

Bremner, J.M. 1996. Nitrogen-total. In: D.L. Sparks et al., editors, Methods of soil analysis, part 3. ASA, Madison, WI. p. 1085-1122.

Bremner, J.M., and F. Führ. 1966. Tracer studies of the reaction of soil organic matter with nitrite. Pergamon Press, Oxford, UK.

Bremner, J.M. 1965. Inorganic forms of nitrogen. In: C.A. Black, editor, Methods of soil analysis, part 2. ASA, Madison, WI. p. 1179-1237.

Cleemput, O., and A.H. Samater. 1995. Nitrite in soils: Accumulation and role in the formation of gaseous $\mathrm{N}$ compounds. Nutr. Cycling Agroecosyst. 45:81-89.

Collot, A.G. 2006. Matching gasification technologies to coal properties. Int. J. Coal Geol. 65:191-212. doi:10.1016/j.coal.2005.05.003

Coyne, M.S. 1999. Soil microbiology: An exploratory approach. Delmar, New York.

De Jager, P.C., J.G. Annandale, I. Mbakwe, and B.H. Sukati. 2011. The potential of sludge amended combustion coal ash residues as soil media:
A laboratory column study to assess the influence of weathering on the elemental release. Water Research Commission Report K5/1724/3. Pretoria, South Africa.

Dendooven, L., R.J. Alcántara-Hernández, C. Valenzuela-Encinas, M. LunaGuido, F. Perez-Guevara, and R. Marsch. 2010. Dynamics of carbon and nitrogen in an extreme alkaline saline soil: A review. Soil Biol. Biochem. 42:865-877. doi:10.1016/j.soilbio.2010.02.014

Fang, M., J. Wong, K. Ma, and M. Wong. 1999. Co-composting of sewage sludge and coal fly ash: Nutrient transformations. Bioresour. Technol. 67:19-24. doi:10.1016/S0960-8524(99)00095-4

Fox, R., K. Iversen, G. Roth, and W. Piekielek. 1989. Soil and tissue nitrate tests compared for predicting soil nitrogen availability to corn. Agron. J. 81:971-974. doi:10.2134/agronj1989.00021962008100060025x

Gil, M.V., M.T. Carballo, and L.F. Calvo. 2011. Modelling N mineralization from bovine manure and sewage sludge composts. Bioresour. Technol. 102:863-871. doi:10.1016/j.biortech.2010.09.010

Ginster, M., and R.H. Matjie. 2005. Beneficial utilization of Sasol coal gasification ash. Paper presented at: World of Coal Ash (WOCA), Lexington, KY, 11-15 Apr. 2005.

Hameed, M., and M. Ashraf. 2008. Physiological and biochemical adaptations of Cynodon dactylon (L.) pers. from the salt range (Pakistan) to salinity stress. Flora 203:683-694. doi:10.1016/j.flora.2007.11.005

Haynes, R. 2009. Reclamation and revegetation of fly ash disposal sites: Challenges and research needs. J. Environ. Manage. 90:43-53. doi:10.1016/j.jenvman.2008.07.003

Henry, C., D. Sullivan, R. Rynk, K. Dorsey, and C. Cogger. 1999. Managing nitrogen from biosolids. Washington State Department of Ecology, Seattle, WA

Hernández, T., R. Moral, A. Perez-Espinosa, J. Moreno-Caselles, M. PerezMurcia, and C. Garcia. 2002. Nitrogen mineralisation potential in calcareous soils amended with sewage sludge. Bioresour. Technol. 83:213219. doi:10.1016/S0960-8524(01)00224-3

Isobe, K., K. Koba, Y. Suwa, J. Ikutani, M. Kuroiwa, Y. Fang, M. Yoh, J. Mo, S. Otsuka, and K. Senoo. 2012. Nitrite transformations in an $\mathrm{N}$-saturated forest soil. Soil Biol. Biochem. 52:61-63. doi:10.1016/j. soilbio.2012.04.006

Jala, S., and D. Goyal. 2006. Fly ash as a soil ameliorant for improving crop production: A review. Bioresour. Technol. 97:1136-1147. doi:10.1016/j. biortech.2004.09.004

Jovanovic, N., J. Annandale, A. Van der Westhuizen, and J. Steyn. 2004. Monitoring the effect of irrigation with gypsiferous mine wastewater on crop production potential as affected by soil water and salt balance. J. S. Afr. Inst. Min. Metall. 104:73-82.

Khan, M.A., I.A. Ungar, and A.M. Showalter. 1999. Effects of salinity on growth, ion content, and osmotic relations in Halopyrum mucronatum (L.) stapf. J. Plant Nutr. 22:191-204. doi:10.1080/01904169909365617

Martines, A.M., M.A. Nogueira, C.A. Santos, A.S. Nakatani, C.A. Andrade, A.R. Coscione, H. Cantarella, J.P. Sousa, and E.J.B.N. Cardoso. 2010. Ammonia volatilization in soil treated with tannery sludge. Bioresour. Technol. 101:4690-4696. doi:10.1016/j.biortech.2010.01.104 
Matjie, R., M. Ginster, C. Van Alphen, and A. Sobiecki. 2005. Detailed characterisation of Sasol ashes. Proceedings of the 2005 World of Coal Ash (WOCA), 11-15 Apr. 2005, Lexington, KY.

Matjie, R.H., Z. Li, C.R. Ward, and D. French. 2008. Chemical composition of glass and crystalline phases in coarse coal gasification ash. Fuel 87:857869. doi:10.1016/j.fuel.2007.05.050

McClung, G., and W. Frankenberger. 1985. Soil nitrogen transformations as affected by salinity. Soil Sci. 139:405-411. doi:10.1097/00010694-198505000-00005

Mears, P. 1970. Kikuyu (Pennisetum clandestinum) as a pasture grass. Trop. Grassl. 4:139-152

Minchener, A.J. 2005. Coal gasification for advanced power generation. Fue 84:2222-2235. doi:10.1016/j.fuel.2005.08.035

Nelson, D.W., and J.M. Bremner. 1969. Factors affecting chemical transformations of nitrite in soils. Soil Biol. Biochem. 1:229-239. doi:10.1016/0038-0717(69)90023-6

Nelson, D.W., and J.M. Bremner. 1970. Gaseous products of nitrite decomposition in soils. Soil Biol. Biochem. 2:203-204. doi:10.1016/0038-0717(70)90008-8

Nishio, T., and T. Fujimoto. 1990. Kinetics of nitrification of various amounts of ammonium added to soils. Soil Biol. Biochem. 22:51-55. doi:10.1016/0038-0717(90)90059-9

Nobela, L. 2011. Influence of biosolid stability, temperature and water potential on nitrogen mineralisation in biosolid amended soils. MSc diss., University of Pretoria, Pretoria, South Africa.

Pathak, H., and D. Rao. 1998. Carbon and nitrogen mineralization from added organic matter in saline and alkali soils. Soil Biol. Biochem. 30:695-702. doi:10.1016/S0038-0717(97)00208-3

Rowell, D.M., C.E. Prescott, and C.M. Preston. 2001. Decomposition and nitrogen mineralization from biosolids and other organic materials. J. Environ. Qual. 30:1401-1410. doi:10.2134/jeq2001.3041401x

SAS Institute. 2002. PROC user's manual, version 9.1. SAS Inst., Cary, NC.

Scholl, D.G., and C.P. Pase. 1984. Wheatgrass response to organic amendments and contour furrowing on coal mine spoil. J. Environ. Qual. 13:479-482. doi:10.2134/jeq1984.00472425001300030030x
Shen, Q.R., W. Ran, and Z.H. Cao. 2003. Mechanisms of nitrite accumulation occurring in soil nitrification. Chemosphere 50:747-753. doi:10.1016/ S0045-6535(02)00215-1

Smith, J.L., R.R. Schnabel, B. McNeal, and G. Campbell. 1980. Potential errors in the first-order model for estimating soil nitrogen mineralization potentials. Soil Sci. Soc. Am. J. 44:996-1000. doi:10.2136/ sssaj1980.03615995004400050025x

Smith, R.V., R.M. Doyle, L.C. Burns, and R.J. Stevens. 1997. A model for nitrite accumulation in soils. Soil Biol. Biochem. 29:1241-1247. doi:10.1016/ S0038-0717(97)00028-X

Tandy, S., J.R. Healey, M.A. Nason, J.C. Williamson, and D.L. Jones. 2009. Remediation of metal polluted mine soil with compost: Co-composting versus incorporation. Environ. Pollut. 157:690-697. doi:10.1016/j. envpol.2008.08.006

Tesfamariam, E.H., J.G. Annandale, J.M. Steyn, and R.J. Stirzaker. 2009. Exporting large volumes of municipal sewage sludge through turfgrass sod production. J. Environ. Qual. 38:1320-1328. doi:10.2134/jeq2008.0397

Tsadilas, C., T. Matsi, N. Barbayiannis, and D. Dimoyiannis. 1995. Influence of sewage sludge application on soil properties and on the distribution and availability of heavy metal fractions. Commun. Soil Sci. Plant Anal. 26:2603-2619. doi:10.1080/00103629509369471

Van den Berg, J.A. 2004. The utilisation of the ash disposal system as a salt sink: Enhancement and optimisation of chemical interactions. MSc diss., University of Stellenbosch, Stellenbosch, South Africa.

Van Rensburg, L., R.I. De Sousa Correia, J. Booysen, and M. Ginster. 1998. Land reclamation: Revegetation on a coal fine ash disposal site in South Africa. J. Environ. Qual. 27:1479-1486. doi:10.2134/ jeq 1998.00472425002700060026x

Zevenbergen, C., J.P. Bradley, L.P. van Reeuwijk, A. Shyam, O. Hjelmar, and R.N.J. Comans. 1999. Clay formation and metal fixation during weathering of coal fly ash. Environ. Sci. Technol. 33:3405-3409. doi:10.1021/ es 9900151 